\title{
Human Resources Development Strategy and its Role in Promoting Employees Strategic Thinking Competencies: A Study at Jordanian Information Technology Companies
}

\author{
Dr. Sahar Moh'd Abu Bakir \\ Associate Professor, Business Administration Department, \\ Amman Arab University, Jordan
}

Doi:10.19044/esj.2019.v15n4p238～URL:http://dx.doi.org/10.19044/esj.2019.v15n4p238

\begin{abstract}
This study aimed to explore the role of human resources development strategy (training, development and learning programs) in promoting employees strategic thinking competencies at the Jordanian (IT) companies. Recently these companies are confronting unprecedented competition; the number of organizations that are offering similar (IT) services is increasing in the Jordanian market; consequently the need for highly skilled innovative employees is essential to maximize the benefits of future opportunities and avoiding threats. It was proved through strategic management research that strategic thinking is the corner stone in successful strategic planning; strategic thinkers represented the inimitable competitive advantage. Accordingly based on the analytical quantitative methodology this study evaluated the role of Jordanian (IT) companies' endeavors in promoting employees' strategic thinking competencies. 140 companies participated in the survey, and from each company human resources and operations managers were selected to fill the study's questionnaire, the results of the study implied that the surveyed companies are engaged in formulating and implementing development strategy's three programs, and there is a statistically significant relationship and impact of development and learning programs on enhancing strategic thinking competencies. Meanwhile the training programs have nonstatistically relationship or impact on enhancing employees' strategic thinking competencies. Moreover the study's results revealed that the newly graduate employees lacked strategic thinking competencies. Relying on the study's results it was recommended modifying the content of training programs, and to induce the strategic thinking competencies within the main (IT) courses at the Jordanian Universities.
\end{abstract}


Keywords: Human Resources Development Strategy, Strategic Thinking Competencies, Jordanian Information Technology Companies

\section{INTRODUCTION}

Business organizations today are working in a challenging uncertain environment, rapid technological advancement and diffusion (Imran, \& Tanveer, 2015), moreover globalization, all these forced new patterns of competition that exceed the local level into the international (Cortada, 2014).

According to Kotler \& Keller (2012) the evolution of information and communication technology creates highly knowledgeable demanding customers with unlimited needs and expectations; based on these conditions Smith et al., (2012) pointed that traditional reactive operations are not sufficient any more to satisfy customers' needs or to achieve competitive edge, organizations must rely on creativity, innovation, flexibility and speed in introducing novelty with value added as Krajewski et al., (2013) recommended.

From the view of Díaz-Fernández et al., ( 2014) and Werner, \& DeSimone, (2012) coping with ongoing changes, and building robust sustainable competitive advantage necessitate competent human resources who are able to undertake accurate forecasting, business Intelligence and proactive strategic planning( Bakir, 2017).

Khan (2014); Salavati et al., (2017) pointed that human resources roles are no longer limited to implementing strategies, they became strategic partners in setting organizations future. Even though Dessler (2014) and Goldman et al., (2015) argued that strategic partnership is not an easy job for human resources to be engaged in; they must be equipped with the strategic thinking skills and competencies either by using formal or informal development programs.

Jordanian (IT) companies, similar to other business organizations in the world, they are operating in a complex and unstable environment. These challenges are raised with the continuous migrations from neighboring countries, which began in 1990 to the present time; the migrations have led to an increase in investment in this sector as well as maximizing competition (Naser, 2015). In the last few years many of Jordanian (IT) companies, particularly small startups failed. Kateb, et al., (2015) identified group of failure reasons, one of these is the lack of qualified staff, (specially the newly graduate employees) in terms of understanding fully the needs of customers, and the shortage in innovative competencies to fulfill all the requirements of the companies' strategic positioning properly, Kateb, et al., (2015) added also that these companies failed also because they are concentrating on short term profits. In their research they introduced insights of the critical contribution of 
strategic thinking competencies in improving the performance of Jordanian (IT) Companies.

Hence this study aimed at assessing the role of human resources development strategy in promoting the staff strategic thinking competencies in Jordanian (IT) companies.

\section{PROBLEM OF THE STUDY AND ITS' SIGNIFICANT}

According to (The Information Technology Association of Jordan INTAJ) Jordanian information technology (IT) companies have developed rapidly in the last five years, representing one of the basic sectors in the Jordanian economy especially with the entry of many non-Jordanian companies into the market. (INTAJ) reported that the total investment in information technology sector in Jordan exceed 2 billion JDs. in (2017), exporting to more than 35 country, these developments increased the challenges that Jordanian (IT) companies confront. Consequently the expectations of human resources roles in these companies has therefore maximized to achieve sustainable inimitable competitive advantage, to capture opportunities before competitors, and to meet customers' needs and the growing demands.

Moreover the results of the survey conducted on Jordanian (IT) companies during 2016 and repeated after by (INTAJ), revealed that most of the sector's companies believed that human resources particularly newly graduates do not have the necessary skills to uphold sectors 'performance, mainly the skills of strategic and critical thinking, in addition to technical skills in problem solving and decision making.

Therefore it was recommended that the (IT) companies are better to be involved in specialized human resources development. So that this study is trying to answer the following questions:

1. Do newly graduate employees in Jordanian (IT) companies lack strategic thinking competencies?

2. Do Jordanian (IT) Companies engage in formulating and implementing human resources development strategy (training, development, and learning programs)?

3. Is there a correlation between human resources development strategy (training, development, and learning programs) and promoting employees strategic thinking competencies?

4. Is there an impact of human resources development strategy (training, development and learning programs) on promoting strategic thinking competencies? 


\section{STUDY'S MODEL AND HYPOTHESES}

Independent Variable/s

Development strategy

-Training programs

\section{-Development programs}

\section{-Learning programs}

- Assessing the development needs

- Designing the development strategy programs.

- Implementing the development strategy programs.

- Evaluating programs
Dependent Variable/s

Strategic Thinking Competencies

- Holistic perspective

- Complementary interactive internal relationships

-Time (future orientation)

- Visionary capabilities

- Clear future intent -Intelligent opportunities orientation

- Catch and invest in opportunities

- Identify and avoid threats

-Creative problem solving

Diagnosing, Analyzing, Developing alternatives, Selecting the proper solution

\section{Study's hypotheses:}

The study attempts to test the following null hypotheses:

Ho1: Newly graduate employees in Jordanian (IT) companies don't lack strategic thinking competencies (systems thinking, time future orientation, intelligent opportunities orientation and creative problem solving).

Ho2: Jordanian (IT) Companies don't engage in formulating and implementing human resources development strategy (training, development, and learning programs).

Ho3: there is no statistically significant relationship between human resources development strategy (training, development, and learning programs) and strategic thinking competencies (systems thinking, time future orientation, intelligent opportunities orientation and creative problem solving).

Ho4: there is no statistically significant impact of human resources development strategy (Training, Development, and Learning programs) on strategic thinking competencies (systems thinking, time future orientation, intelligent opportunities orientation and creative problem solving).

\section{LITERATURE REVIEW AND THEORETICAL BACKGROUND}

\subsection{Development Strategy:}

It has become a fact that strategic human resources management does not end with the completion of staffing procedures. All employees must be provided with the right skills to perform current and future tasks as planned (Torrington et al., 2011). Recently most organizations are aware of the need to reinforce the capabilities of their staff, they devote resources and efforts to 
build and implement a useful human resources development strategy (Mello, 2015). According to Nolan (2002) the term development strategy introduced in 1970 by Leonard Nadler to express a group of organized activities and learning experiences that aim to boost the skills and competencies of individuals and prepare them to lead organizations growth.

For Ivancevich (2010) development strategy can be defined as a set of planned programs designed by the organization to support its members with the necessary proficiencies to meet current and future job demands.

Meanwhile Werner \& DeSimone, (2012) and Dessler ( 2014) perceived development strategy as a strategic process composed of integrated, continuous learning programs aimed to promoting organizations intellectual capital.

\subsubsection{Development Strategy's Programs:}

Working on what was introduced in previous literature Armstrong \& Taylor (2014) Identified 4 elements of human resources development strategy (training, development education and learning programs).

In accordance to DeNisi \& Griffen (2010) these programs are performed in an organized sequence, all are having the same actions either in training, development, learning and education programs. .

DeCenzo \& Robbins (2015) illustrated that assessing the development needs is the first stage which is based on collecting the information concerning the needed skills and competencies that had to be available to achieve organizations objectives.

According to Noe (2013) any mistake in needs assessment will result in resources waste, and deficiency in goals attainment. The second step is designing the development strategy programs, this step embraces setting the development objectives, determining the content of the program, identification of development methods, selection of competent trainers, and preparing all the necessary resources and facilities to make the transfer into the third stage ( implementation of the development strategy programs) easier (AmoahMensah \& Darkwa, 2016).

After completing the programs as planned the last stage is evaluating the effectiveness of the programs, and the extent of improvement in trainees' abilities, skills knowledge, and behavior achieved as a result of the provided programs (Ahmad et al., 2014).

In spite of the homogeneity in the planning implementation process each of the development strategy's programs has its own characteristics (Armstrong \& Taylor, 2014). 


\section{Training programs:}

Training can be defined as a systematic activities that aimed to reinforcing human resources skills and knowledge to perform their current tasks properly (Noe , 2013),

DeCenzo \& Robbins (2015) perceived training as an organizational attempts to make a positive change in employees attitudes, behavior, furthermore Robbins \& Coulter (2012) view training as a set of organized actions aimed at changing human resources trends and behavior to achieve organization objectives.

Bernadin \& Russell (2013) commented that training is the organizational efforts aimed to provide all staff with the necessary capabilities to perform their current tasks efficiently and effectively.

\section{Development programs:}

Like training, development programs encompass group of organized activities, but it has wider objectives in scope and content, development is directed by organization's future intent and how it will accomplish its strategic purposes (Mello, 2015).

The basic goals of development programs are to make sure that the needed future talents are available and the expected future jobs will be occupied by the adequate qualifications ( Dessler, 2014).

Noe, (2013) emphasized that both types of programs are necessary in organizations; the training for achieving short term objectives and the long term strategic objectives can be attained through development programs.

\section{Learning Programs.}

According to Armstrong \& Taylor (2014) learning can be defined as “

The process, by which the individual obtains, generates and develops knowledge, capabilities, skills, attitudes and behaviors". It embraces the modification of behavior at work through planned formal programs as well as informal and from experience learning (Buchanan, \& Huczynski, 2010).

However Robbins \& Judge , (2013) commented that informal learning, is unplanned, mostly it took place at work, where employees get knowledge and skills through their own practical practice, they learn from their mistakes , and repeat their achievements, or by observing others behavior (employees, supervisors, managers, and customers also).

\section{Levels of learning}

Argyris (1991) argued that learning in organizations has two levels; single and double loop learning, he mentioned that single loop is acquired through conventional training, development and education programs, and 
enables employees to discover the best methods to solve problems and to fix any deviation from the expected results.

However the double loop learning is navigating deeper; according to Senge (1990), it involved building employees personal mastery, changing their mental models to cope with the changes in the surrounding environment, the double loop learning utilized in creativity and critical thinking.

Pahl-Wostl, (2009) stated that a third type of learning (Triple-Loop Learning) has inspired also from Argyris theory of learning, the triple loop introduced to express the notion of (Learning About Learning) it is double loop learning of the double loop learning.

Abraham (2005) stated that strategic thinking is related to double loop and most likely to the triple loop learning.

\section{Education programs:}

Previous research highlighted positive link between the level of education and human resources capabilities, and their ability to understand and perform their job requirements easier as Bohlander \& Snell (2013) stated.

Education level is one of the main requirements for recruiting and selecting qualified human resources (Ivancevich, 2010). According to Daft, (2012) the significance of education increased over years due to technological progress and complications in the external environment, these situations imposed a change in the structure of jobs that constantly needs higher levels of education.

Education makes people more receptive to new ideas and more aware of ways of performing tasks as (Robbins \& Coulter, 2012) pointed.

\subsubsection{Development strategy outcomes}

Development strategy programs are planned efforts, formulated and implemented to achieve clear specific and measurable objectives (Bohlander \&Snell, 2013). Many researchers pursue to study the outcomes of these programs at the individual and at the organization's levels (Kum et al., 2014).

Saleem et al., (2011) pointed out that training and development affect the moral of employees, enhance their self-esteem and raise their job satisfaction,

Hanif (2013) results indicated that training and development consolidate creativity capabilities of hotels employees which reflected in innovative organizational performance.

Tahir et al., (2014) study at Pakistanis banking sector found that there is a link between training and development and banks employees' productivity and work quality.

Obi-Anike et al., ( 2014) deduced a positive relationship between training and development and the Nigerian public sector organizations. 
Falola et al., (2014); Imran \& Tanveer, (2015) concluded that there is a positive association between training and development and employees productivity at the banking sector in Pakistan .

Ahmad et al., (2014) proved that there is a positive impact of training and development on the performance of banking sector employees at Punjab region.

Ugbomhe et al., (2016) stated that development strategy programs increased employees skills and motivated them for better outputs.

Habib, \& Essien, (2016) treated training as a motivator for enhancing satisfaction of Sheraton Hotel employees at Nigeria , and consequently their performance improved .

Meanwhile Moh'd (2013) mentioned that training and development are stimulators for employees citizenship behavior and commitment.

In Jordan many researchers as well studied the outcomes training and development had on employees' performance and attitudes.

Altarawneh, (2005) examined the relationship between the effectiveness of training and development programs and the performance of both employees and organizations at the Jordanian commercial banks, her results emphasized the positive association between the studied variables.

Bataineh, K. (2014) studied one of the Jordanian commercial banks, his results matched other researchers findings in terms of that training and development upholding employees motivation and performance, and furthermore improve the Jordanian Housing Bank productivity.

Al-Qudah et al., (2014) found a positive connection between training and development and boosting the skills of the Jordanian public sector employees and in return the organizational performance enhanced as so.

Al-Mzary, et al., (2015) concluded that training and development raised the capabilities of Al- Yarmouk university's employees. Moreover Abu Rumman \& Al-Rahahalh, (2016) found the same results but at al AlBalqa' Applied University.

Abdulraheem (2016) inspected the link between training and development programs and employees productivity at private transportation companies operating in Southern region of Jordan, the findings inferred an improvement of employees overall performance as a result of the provided programs.

\subsection{Strategic Thinking:}

Until the end of the last century, the concept of strategic thinking was associated with strategic planning and strategic management.

Wheelen \& Hunger (2012) argued that strategic management is about strategic planning and strategic thinking. In this context Kurec, (2014) pointed out that strategic thinking treated as one of prerequisites of strategic 
management; meanwhile strategic planning focuses on attaining the right information and developing the vision, mission, objectives, and strategies, strategic thinking, is creating synthesis through aligning the organization's structure to its strategic plan (David, 2011).

According to Lowder (2009) "Strategic thinking and strategic planning are two pieces of the same puzzle,"they are (mutually dependent).

In fact the concepts has its significance years before what was introduced; Liedtka, (1998) highlighted the degree to which strategic thinking is crucial to business organizations, she defined strategic thinking as a combination of analytical, conceptual, visionary and synthesizing skills utilized to formulate strategies and strategic decisions that will make the organization competitive even with limited resources. O'Shannassy, (2003) described strategic thinking as a deep nonlinear, creative, innovative, intuitive, divergent, synthetic, rational, analytical, and imaginative (long term) way of thinking.

Bonn ( 2005) denoted that most of the researchers counted on Mintzberg perception of strategic thinking, in his article titled "The fall and rise of strategic planning" which was published in (1994). Mintzberg portrayed strategic thinking as a process of creative synthesis and integration of the organization's parts. However, Goldman et al., (2015) pointed out that strategic thinking is a process of gathering, analyzing, evaluating information and ideas to be used to obtain organizational sustainability.

It is apparent from the above mentioned definitions there is an approval among thinkers on the essence of strategic thinking.

\subsubsection{Elements of Strategic Thinking}

Although there are many assumptions about the components of strategic thinking, there is consensus that strategic thinking involves group of elements formed the core of the competencies the strategic thinker must have.

Mintzberg (1994) was the pioneer in introducing the core of strategic thinking concept, meanwhile Liedtka, (1998) developed a model of strategic thinking consisted of five elements " system perspective, intent focused, thinking in time, Intelligent opportunism and hypothesis driven" most of those who came after relied on Liedtka's model e.g. O'Shannassy, T. (2003), Nuntamanop et al., (2013); Salavati et al., (2017); Goldman \& Scott ( 2016).

Bonn (2001) proposed three elements of strategic thinking started with systemic thinking, creativity and the ability to look ahead and determine the future vision for the organization.

Meanwhile MTD Training (2010) demonstrated the elements of strategic thinking away from the five components of (Liedtka) model.

(MTD Training) indicated that strategic thinking is built on 6 Ps; basically the strategic thinker should be able to go through their details and 
control them in a way that he/ she keeps pace with changes in the internal and external environment of the organization.

Purpose: is the first $\mathrm{P}$, it is related to the ability to construct the general intentions of the organization's future and to draw the map for every step after. The second P is Plan, one of the strategic thinker fundamental tasks is setting SMART objectives and building the right strategies to attain these objectives.

Ploy is the third which referred to the awareness of competitors excellence areas, and their pitfalls, the purpose is to navigate through own strengths and finally outperform competitors.

The fourth is Position (strategic positioning); the strategic thinker must identify the target market and work hard to excel in attracting and retaining customers.

Pattern is the fifth element; after creating the previous four elements strategic thinking became the norm in the organization operations.

Finally Push: by energizing all organizations' members towards achieving the strategic objectives within teams' spirit and collective efforts.

For the purpose of this study the researcher adopted 4 elements of Liedtka (1998) model as follows:

\section{Systems Perspective (Holistic perspective)}

Systems' thinking is a holistic approach of seeing the constitutions parts of the organization as one unit, it expresses the interrelationship and the complementary mood of the subsystems (Richmond, 1993).

The concept was introduced by Senge in (1990) in his book the fifth discipline, Senge shed light on two components of systems thinking; the (internal systems thinking) between the organizations' sections, and the external systems thinking which explains the mutual effect between the organization and the external environment.

According to O'Shannassy, (2003) the systems perspective facilitates critical thinking for analyzing and diagnosing problems, it provides the individual with a comprehensive view of all the problem causes and all the alternatives to find the appropriate solutions.

It is a clear mental picture of a value creation complete system which treated the organization as one synergic entity (Al-Qutop, et al., 2011).

\section{Time (future orientation)}

In accordance to Liedtka (1998) this dimension referred to the long term vision and the clear future intent the organization seeks to build.

According to Goldman et al., (2015) thinking in time and being future oriented necessitate a clear strategic intent. Since the responsibility for formulating strategies moved from the top levels to the employees too; there must be a clear, understanding from all employees of the organization's future 
direction. All the efforts are working towards achieving the strategic goals without any ambiguity and confusion in what is required of them, (Nuntamanop, et al., 2013).

Strategic thinking builds this future intent at the individual and then at the organization's level (Bakir, 2017).

\section{Intelligent opportunities orientation}

Intelligent Opportunism as it was called by Liedtka (1998) is a notion that is connected with getting benefit of the openness to experiences and smartly coping with the changes in business environment.

Catching the right opportunities is not the task of managers anymore; creative employees have the major contribution in finding innovative methods in competing and raising customers value (Abraham, 2005). Strategic thinkers have sufficient capabilities to survey the external environment with its components and to continuously monitor changes that could occur in order to discover and invest in opportunities before competitors (Pattinson, 2016), and at the same time they can identify threats in the external environment and work to reduce or avoid risks if possible (Sharifi,2012).

\section{Creative problem solving}

In accordanc to Kurec, (2014) strategic thinkers are likely to use divergent, holistic thinking in diagnosing and analyzing problems; they are creative in developing alternatives, solutions and scenarios to solve strategic problems.

\subsubsection{Outputs of strategic thinking}

to achieve the positive outcomes of strategic thinking Bonn (2001) discussed that strategic thinking necessitates to be addressed in organizations at two interrelated levels: at the major organizational level, and at the minor individual level.

In Bonn (2005) he mentioned also that the complementary endeavors formed a core competency and robustness for sustainable competitive advantage.

Abraham, (2005) commented that strategic thinking is a strength point that expand the organization capabilities for excellence.

However French (2009) argued that since organizations are operating in a changing setting, strategic thinking is likely to provide them with the ability to build strategies in compatible with the situations they operate in. In the same context Calrk, (2012) and Nuntamanop et al., (2013) illustrated that strategic thinking lead to good strategic planning and rational decisions in addition to successful implementation of organizational strategies. 


\section{Research Methodology:}

\subsection{Study's population, sample, and sampling unit}

Jordanian Information Technology (IT) Companies formed the population of the study.

According to (INTAJ, 2017 report) Jordan has more than 600 companies operating in the field of telecommunications and information technology, which helped to provide about 16,793 jobs in all around the Kingdom, these companies contributed significantly to Jordanian GDP.

Hence the government of Jordan encourages and supports investment in this sector, particularly the emerging companies which are eager to attract qualified human resources.

The researcher selected randomly 140 companies, operating at Amman city, and next from each company the operations manager, and human resources manager were involved in the survey.

It is known that these two functional managers have closed contact with employees and they are able to identify employees' weakness points and the competencies their subordinates have. Accordingly 280 questionnaires were distributed, out of them 243 retrieved, and 238 were credible to be statistically analyzed.

\subsubsection{Respondents' characteristics:}

As was mentioned above 238 questionnaire were valid for statistical analysis, represented the number of respondents, $79 \%$ of them are males, while $21 \%$ females, this gap is due to the long working hours that must be spent to fulfill job requirements, most Jordanian females prefer to work at organizations which have fixed (8) working hours.

When it comes to education all respondents had university degrees, and they had more than 5 years job experience in the same sector, which support the reliability of their answers.

\subsection{Measures and tool of the study:}

Following what was introduced by Armstrong \& Taylor (2014) the independent variable (human resources development strategy) is measured through 3 programs (training, development and learning). Armstrong \& Taylor (2014) considered education the fourth element of human resources development strategy.

In spite of that education was excluded because Jordanian (IT) companies are not engaged in education programs, but in return they are enthusiastic to attract highly educated employees.

Based on Liedtka (1998) and O'Shannassy, (2003) strategic thinking competencies, are measured through four dimensions (Systems thinking, Time 
(future) orientation, Intelligent opportunities orientation and creative problem solving).

To collect the needed data the researcher developed a questionnaire consisted of 4 parts, the first measured the functional and demographic characteristics of the respondents, including gender, education, and work experience.

The second part contained 20 questions aimed to measure the degree to which respondents (the operations and human resources managers) perceived newly graduate employees lack strategic thinking competencies.

The third part measured the degree to which the surveyed companies are engaged in formulating and implementing human resources development strategy (training, development and learning programs).

While the fourth part encompassed questions measured the level of strategic thinking competencies employees acquired as a result of development strategy's programs.

To estimate the level of responses the five-dimensional Likert scale ranging from strongly disagree (1) to strongly agree (5).

\subsubsection{Questionnaire's validity:}

In accordance to Zikmund (2003) validity examined if the questionnaire questions reflected appropriately the variables of the study, to check the face validity of the questionnaire it was revised and confirmed by group of human resources management instructors.

\subsubsection{Questionnaire's Reliability:}

Sekaran (2003) clarified that reliability is about the internal consistency of the questionnaire and the degree of correlation between the questions that measured each variable.

According to Saunders et al., (2013) Cronbach Alpha is the most commonly used measure of internal consistency, subsequently Cronbach Alpha was calculated for the questions that measure each of the programs of human resources development strategy, and for the questions that measure each of the 4 competencies of strategic thinking. The results in table (1) show that all values are higher than the acceptable value of the test which is $70 \%$, based on Sekaran (2003).

Table (1) Cronbach Alpha results

\begin{tabular}{|c|c|c|c|}
\hline Variable/s & $\begin{array}{c}\text { Cronbach } \\
\text { Alpha value }\end{array}$ & Variable/ s & $\begin{array}{c}\text { Cronbach } \\
\text { Alpha value }\end{array}$ \\
\hline $\begin{array}{c}\text { Independent variable } \\
\text { (development strategy) }\end{array}$ & 0.864 & $\begin{array}{c}\text { Dependent variable ( strategic } \\
\text { thinking competencies ) }\end{array}$ & 0.872 \\
\hline Training programs & 0.813 & Systems thinking & 0.781 \\
\hline Development programs & 0.795 & Time (future orientation) & 0.844 \\
\hline Learning programs & 0.881 & Intelligent opportunities orientation & 0.805 \\
\cline { 2 - 4 } & & Creative problem solving & 0.790 \\
\hline
\end{tabular}




\section{STATISTICAL ANALYSIS RESULTS}

In this section the researcher presents in details the results of the statistical analysis methods that are utilized for answering the research questions and testing hypotheses.

Depending on the "Statistical Package for the Social Sciences" (SPSS) the researcher used the following statistical methods:

\section{The Descriptive statistics:}

-The arithmetic mean as one of the central tendency measures used to express respondents' degree of agreement on the study's questions content.

-The standard deviation: as one of the dispersion measures used to express the data spread from its mean.

\section{The Inferential statistics:}

-One sample t test: to examine the first and the second hypotheses.

-Pearson Correlation Coefficient: to test the third hypothesis.

-Multiple linear regression: used to test the fourth hypothesis relying on the "The linear regression equation: " $\mathrm{Y}=\mathrm{B} 0+\mathrm{B}_{1} \mathrm{X}_{1}+\mathrm{B}_{2} \mathrm{X}_{2}+\mathrm{B}_{3} \mathrm{X}_{3}+\mathrm{E}$.

\subsection{Descriptive statistics results}

To measure the level of participants' agreement on the study's questions, the arithmetic mean and standard deviation were calculated.

Table (2) manifests in a descending order the total arithmetic means of the development strategy's programs, it is clear in comparison with the test value (3) that all the programs means exceed this value, from the participants point of view the companies they work at are eager to build and implement human resources development strategy relying on accurate assessment of training needs, and taking into consideration coping with the innovative methods in promoting employees skills. The surveyed companies are preparing the staff for current and future jobs and also for environmental uncertainty.

Table (2) Descriptive statistics results of the Development Strategy

\begin{tabular}{|c|c|c|c|}
\hline Development strategy & Mean & Std. Deviation & Std. Error Mean \\
\hline Development programs & 4.1961 & .35485 & .02300 \\
\hline Learning programs & 3.568 & .67145 & .04352 \\
\hline Training programs & 3.3761 & .58830 & .03813 \\
\hline \multicolumn{4}{|c|}{$\mathbf{N = 2 3 8}$} \\
\hline
\end{tabular}

Table (3) displays in a descending order the total means of the respondents answers on the questions related to the strategic thinking competencies, the participants were asked if the newly graduated staff lacked strategic thinking competencies.

All the total arithmetic means exceed (3) with a standard deviation less than (1) which indicated that there is an agreement among the respondents that newly graduate employees don't have sufficient levels of creative problem 
solving and they lack methods of shared future vision, in addition they are not aware enough of the holistic view of the organization and the integrative relationship between organizations' parts internally and the mutual effect of the relationship with the external environment. The results signalized also that the newly graduate employees lack the talent to assess and catch the external opportunities and they need to be alert of the rational methods to invest in these opportunities.

Table (3) Descriptive statistics results of Strategic Thinking Competencies

\begin{tabular}{|c|c|c|c|}
\hline $\begin{array}{c}\text { Strategic thinking } \\
\text { competencies }\end{array}$ & Mean & Std. Deviation & $\begin{array}{c}\text { Std. Error } \\
\text { Mean }\end{array}$ \\
\hline Creative problem solving & 3.5924 & .39494 & .02560 \\
\hline Time ( future) orientation & 3.3668 & .61042 & .03957 \\
\hline Systems thinking & 3.2290 & .61373 & .03978 \\
\hline $\begin{array}{c}\text { Intelligent opportunities } \\
\text { orientation }\end{array}$ & 3.1576 & .58764 & .03809 \\
\hline
\end{tabular}

$\mathbf{N}=238$

\subsection{Hypotheses testing results}

To test the first and the second hypotheses one sample t test with (test value $=3$ ) and $\mathrm{p}$ value $=0.05$ are used. According to Sekaran (2003) the null hypothesis will be rejected if the sig level results of the tested variables are less than $\mathrm{p}$ value $(0.05)$.

\section{The first hypothesis results}

Ho1: newly graduate employees don't lack strategic thinking competencies.

Table (4) displays the results of one sample t test of the first hypothesis,

The table shows that $\mathrm{t}$ calculated for the 4 dimensions of strategic thinking competencies (systems thinking, time/ future orientation, intelligent opportunities orientation and creative problem solving) are respectively $(5.756,6.743,4.136$ and 23.142$)$ at sig levels for them all $=0.000$. Based on the mentioned rule Ho1 will be rejected, to confirm that the newly graduate employees lack strategic thinking competencies.

Table (4) the results of Ho1

\begin{tabular}{|c|c|c|c|c|c|c|}
\hline \multirow{3}{*}{$\begin{array}{l}\text { Strategic thinking } \\
\text { competencies }\end{array}$} & \multicolumn{6}{|c|}{ Test Value $=3$} \\
\hline & \multirow[t]{2}{*}{$\mathbf{t}$} & \multirow[t]{2}{*}{$\begin{array}{l}\text { Df } \\
n-1\end{array}$} & \multirow[t]{2}{*}{$\begin{array}{l}\text { Sig. (2- } \\
\text { tailed) }\end{array}$} & \multirow[t]{2}{*}{$\begin{array}{c}\text { Mean } \\
\text { Difference }\end{array}$} & \multicolumn{2}{|c|}{$\begin{array}{c}\text { 95\% Confidence Interval } \\
\text { of the Difference }\end{array}$} \\
\hline & & & & & Lower & Upper \\
\hline Systems Thinking & 5.756 & 237 & .000 & .22899 & .1506 & .3074 \\
\hline Time (future orientation ) & 6.743 & 237 & .000 & .26681 & .1889 & .3448 \\
\hline $\begin{array}{c}\text { Intelligent opportunities } \\
\text { orientation }\end{array}$ & 4.136 & 237 & .000 & .15756 & .0825 & .2326 \\
\hline Creative problem solving & 23.142 & 237 & .000 & .59244 & .5420 & .6429 \\
\hline
\end{tabular}




\section{The second hypothesis results}

Ho2: Jordanian Information Technology Companies don't engage in formulating and implementing human resources development strategy (training, development, and learning programs). hypothesis

Table (5) shows the results of one sample $t$ test for the second

The values of $\mathrm{t}$ sig for the three programs (training, development and learning) $=0.000$ since they are all less then $\mathrm{p}$ value 0.05 . Based on the previously mentioned rule $\mathrm{Ho} 2$ will be rejected, which inferred that information technology companies do engage in formulating and implementing human resources development strategy (training, development, and learning programs).

Table (5) the results of $\mathrm{Ho} 2$

\begin{tabular}{|c|c|c|c|c|c|c|}
\hline \multirow{3}{*}{$\begin{array}{c}\text { Development strategy } \\
\text { dimensions }\end{array}$} & \multicolumn{6}{|c|}{ Test Value $=3$} \\
\hline & \multirow[t]{2}{*}{$\bar{t}$} & \multirow[t]{2}{*}{ df } & \multirow[t]{2}{*}{$\begin{array}{l}\text { Sig. }(2- \\
\text { tailed) }\end{array}$} & \multirow[t]{2}{*}{$\begin{array}{c}\text { Mean } \\
\text { Difference }\end{array}$} & \multicolumn{2}{|c|}{$\begin{array}{l}\text { 95\% Confidence Interval of the } \\
\text { Difference }\end{array}$} \\
\hline & & & & & Lower & Upper \\
\hline \multirow{3}{*}{$\begin{array}{l}\text { Training programs } \\
\text { Development } \\
\text { programs } \\
\text { Learning programs }\end{array}$} & 16.349 & 237 & .000 & .37605 & .3307 & .4214 \\
\hline & 27.481 & 237 & .000 & 1.19608 & 1.1103 & 1.2818 \\
\hline & 14.838 & 237 & .000 & .56583 & .4907 & .6410 \\
\hline
\end{tabular}

\section{The third hypothesis results}

Ho3: there is no statistically significant relationship between human resources development strategy (training, development, and learning programs) and strategic thinking competencies (systems thinking, time future orientation, intelligent opportunities orientation and creative problem solving).

To test Ho3 the researcher computed Pearson Correlation Coefficient, this measurement

which range from -1 to +1 elucidates the strength and the direction of the relations between variables. The closer the correlation to 1 the stronger the relation is, either positively or negatively (inverse relationship between variables).

The relationship will be treated as statistically significant if the sig level of the correlation between the 2 variables is less than 0.05 ( Zikmund, 2003).

Based on Evans (1996) scale of correlation strengths, if the correlation is $\geq 0.80$ it is treated as very strong relationship, the correlation $(0.60-0.79)$ inferred a strong relationship, meanwhile $(0.40-0.59)$ considered a moderate relationship, and the weak relationship ranged from 0.20 to 0.39 , however less than 0.20 is very weak relationship. 
Table (6) the results of $\mathrm{Ho3}$

\begin{tabular}{|c|c|c|c|c|c|c|c|c|}
\hline \multirow{3}{*}{$\begin{array}{c}\text { Development } \\
\text { strategy } \\
\text { programs }\end{array}$} & \multicolumn{8}{|c|}{ Strategic Thinking competencies } \\
\hline & \multicolumn{2}{|c|}{$\begin{array}{l}\text { Systems } \\
\text { thinking }\end{array}$} & \multicolumn{2}{|c|}{$\begin{array}{l}\text { Time (future } \\
\text { orientation ) }\end{array}$} & \multicolumn{2}{|c|}{$\begin{array}{c}\text { Intelligent } \\
\text { opportunities } \\
\text { orientation }\end{array}$} & \multicolumn{2}{|c|}{$\begin{array}{c}\text { Creative } \\
\text { problem solving }\end{array}$} \\
\hline & $\mathbf{R}$ & Sig & $\mathbf{R}$ & Sig & $\mathbf{R}$ & Sig & $\mathbf{R}$ & Sig \\
\hline Training & .090 & .165 & .047 & .470 & .081 & .216 & .094 & .147 \\
\hline Development & $.633^{* *}$ & 0.000 & $.412^{* *}$ & 0.000 & $.653^{* *}$ & 0.000 & $.666^{* *}$ & 0.000 \\
\hline Learning & $.434^{* *}$ & 0.000 & $475^{* *}$ & 0.000 & $.354^{* *}$ & 0.000 & $.377^{* *}$ & 0.000 \\
\hline
\end{tabular}

Table (6) manifests the results of Pearson Correlation coefficient between development strategy programs and strategic thinking competencies.

It is obvious from the values of $\mathrm{R}(0.09,0.047,0.081,0.094)$ that there is a non-statistically significant (very weak) relationship between training programs and strategic thinking competencies. Meanwhile the relations between development programs and strategic thinking competencies were positive and statistically significant at 0.000 .

Counted on (Evans) rating it is a strong relationship between development programs and systems thinking, intelligent opportunities orientation and creative problem solving, and a moderate relationship between development programs and time / future orientation competency.

The table shows $\mathrm{R}$ values $(0.434,0.475,0.354,0.377)$ which cleared a moderate, positive and statistically significant at 0.000 relationship between learning programs and strategic thinking competencies.

The results indicated that any increase in development and learning programs will accordingly increase the level of employees' strategic thinking competencies.

\section{The Fourth hypothesis results:}

Ho4: there is no statistically significant impact of human resources development strategy

(Training, development, and learning programs) on strategic thinking competencies as one variable (systems thinking, time future orientation, intelligent opportunities orientation and creative problem solving)

To test Ho4 the researcher calculated linear multiple regression with $\mathrm{p}$ value $(0.05)$

Table (7) the results of $\mathrm{Ho} 4$

\begin{tabular}{|c|c|c|c|c|}
\hline \multicolumn{5}{|c|}{ Model summary results \& ANOVA Results } \\
\hline R & R Square & $\begin{array}{c}\text { Adjusted R } \\
\text { Square }\end{array}$ & F & Sig. \\
\hline $.760^{\mathrm{a}}$ & .578 & .573 & 106.062 & $.000^{\mathrm{b}}$ \\
\hline \multicolumn{5}{|c|}{ Coefficients } \\
\hline $\begin{array}{c}\text { Development } \\
\text { strategy }\end{array}$ & B & Beta & $\mathbf{t}$ & T sig \\
\hline
\end{tabular}




\begin{tabular}{|c|c|c|c|c|}
\hline (Constant) & 1.390 & & 5.062 & .000 \\
\hline Training & -.075 & -.050 & -1.162 & .246 \\
\hline Development & .472 & .596 & 12.422 & .000 \\
\hline Learning & .244 & .270 & 5.632 & .000 \\
\hline
\end{tabular}

The acceptance decision of the above mentioned hypothesis will be based on t significant level values. Ho4 will be rejected if $\mathrm{t}$ sig level is less than 0.05 .

For the $4^{\text {th }}$ hypothesis "The linear regression equation" $\mathrm{Y}=\mathrm{B} 0+\mathrm{B}_{1} \mathrm{X}_{1}+\mathrm{B}_{2} \mathrm{X}_{2}+\mathrm{B}_{3} \mathrm{X}_{3}+\mathrm{E}$

Will be presented as follows:

$\mathrm{Y}$ : is the dependent variable (strategic thinking competencies)

$\mathrm{X}_{1-} \mathrm{X}_{3}$ : are the independent variables (development strategy's' programs)

Bo: is the constant.

$\mathrm{B}_{1}-\mathrm{B}_{3}$ : are the regression coefficients.

$\mathrm{E}$ : the error.

Table (7) displays the value of F (106.062) at 0.000 sig level; which is less than 0.05 .

In accordance to Saunders et al., (2013) the ( F sig level) that is less than $\mathrm{p}$ value 0.05 inferred a linear relationship between the independent and dependent variables, in addition to the suitability of the study's model for testing regression.

F sig value also indicated that at least one of the development strategy dimensions (training, development, and learning programs) has an impact on strategic thinking competencies.

The table shows also (R) Pearson correlation (0.760) which explained a positive association between development strategy's dimensions and strategic thinking competencies.

The value of $\mathrm{R}^{2}(0.578)$ indicated that $57.8 \%$ of the variation in strategic thinking competencies is due to development strategy programs, while $42.2 \%$ of strategic thinking competences are acquired by other factors than the three dimensions of the development strategy.

The table shows that the values of $t$ (calculated) and $t$ sig for development strategy's dimensions were as follows:

Training programs: $\mathrm{t}=(-1.162)$ at 0.246 sig level

Development programs $\mathrm{t}=(12.422)$ at 0.000 and for learning programs $\mathrm{t}=(5.632)$ at $0.000 \mathrm{sig}$ level.

The results (based on the acceptance rule) articulated that there is no statistically significant impact of training on strategic thinking competencies due to the value of $\mathrm{t} \operatorname{sig}(0.246)>(0.05)$, 
and at the same time there is a statistically significant impact of both development and learning programs on strategic thinking competencies, due to the value of $\mathrm{t}$ sig level for both variables were less than 0.05 .

The table exhibits Beta coefficients values for the development programs (0.596), and for learning programs (0.270), signalized the strength of impact the two variables have on enhancing employees' strategic thinking competencies.

Meanwhile (-.050) of the training programs indicated no impact of this dimension on strategic thinking competencies.

Also relying on $\mathrm{B}$ results in table (7) and since training has no significant effect on promoting strategic thinking competencies the multiple regression equation will have the following form: (learning).

Strategic thinking competencies $=1.390+.472$ (development $)+.244$

Which means that the increase in development programs by one unit will result in 0.472 increase in strategic thinking competencies, and the same of the learning programs, any increase in one unit will result in .244 increase in strategic thinking competencies.

\section{DISCUSSION AND RECOMMENDATIONS}

Theoretically it was confirmed that the new phase in strategic management relied mainly on strategic thinking; there is consent that strategic thinkers are the energizers for business organization's future success regardless of the field. Thus information technology companies' need for strategic thinkers is escalating particularly with the changing structure of competition.

Although it was proved that strategic thinking competencies are not innate, they are learnable, can be build and developed.

So that this study attempts to discover the role of development strategy in enhancing strategic thinking competencies in Jordanian (IT) companies,

Three types of programs (training, development and learning) are utilized to measure (Human resources development strategy).

While strategic thinking competencies, were measured through four dimensions (Systems thinking Time, ( future) orientation, Intelligent opportunities orientation and creative problem solving.

For collecting the required data and information 140 companies operating in the capital (Amman) were randomly selected, from each company the operations manager and human resources manager were targeted to fill the study's questionnaire, SPSS (22) version used for analyzing the collected data, the results of the study extracted the following conclusions:

Ho1 results revealed that newly graduate human resources in the surveyed companies lack strategic thinking competencies, this result go with 
(INTAJ) study findings which exhibited that (IT) newly graduates didn't have the necessary skills to uphold the sectors' performance, mainly strategic and critical thinking competencies. Jordanian (IT) companies attributed this shortage to the universities programs and the content of the courses provided to the IT students during studying years.

The findings of Ho2 showed that Jordanian IT Companies do engage in human resources development strategy (training, development and learning programs). These results match all what was introduced in the previous literature which underlined the value of development strategy programs in preparing employees for current and future jobs.

The results of $\mathrm{Ho} 3$ disclosed that there is no statistically significant relationship between training programs and strategic thinking competences, meanwhile development and learning programs both had statistically significant relationship with strategic thinking competencies. As well, the results of Ho4 deduced; that development and learning programs have also a statistically significant impact on strategic thinking competencies.

The mentioned findings matched the results of Hanif (2013) Tahir et al., (2014) Obi-Anike et al., (2014); Falola et al., (2014); Imran \& Tanveer, (2015) Ahmad et al., (2014) Habib, \& Essien, (2016) and Oni-Ojo et al., (2014) in terms of the positive relations and effect of development and learning programs, on promoting employees capabilities and performance.

Whilst the results of Ho3 didn't match any of the mentioned studies' when it comes to training programs; the assumed justification is that this type of programs are concerned with enhancing employees skills to perform the current job meanwhile strategic thinking is a concept that is connected mainly with the expected future of the organization.

Based on the study's results it is recommended that the surveyed companies should pay more attention to the content of the training programs; these programs should be comprehensive, to contain current and future jobs requirements.

The second recommendation assured what was introduced by (INTAJ) that Jordanian universities weather private or public are better to respond to the market needs and modify (IT) courses' content accordingly.

For future research it is recommended to examine the impact of strategic thinking at other sectors than the information technology, and taking in considerations some other independent variable /s than the Human Resources Development Strategy.

\section{References:}

1. Abdulraheem Sal, M. R. (2016). The impact of training and development on employees performance and productivity. International Journal of Management Sciences and Business Research, 5, (7), 36-70. 
2. Abraham, S. (2005). Stretching strategic thinking. Strategy \& leadership, 33(5), 5-12.

3. Abu Rumman, M..A \& Al-Rahahalh, N. E. (2016) training strategy and its impact on the performance of employees, European Journal of Business and Management.8, (23), 75-80.

4. Ahmad, N., Iqbal, N., Mir, M. S., Haider, Z., \& Hamad, N. (2014). Impact of training and development on the employee performance: a case study from different banking sectors of north Punjab. Nigerian Chapter of Arabian Journal of Business and Management Review, 62(1882), 1-6.

5. Al-Mzary, M. M. M., Al-rifai, A. D., \& Al-Momany, M. O. E. (2015). Training and Its Impact on the Performance of Employees at Jordanian Universities from the Perspective of Employees: The Case of Yarmouk University. Journal of Education and Practice, 6(32), 128-140.

6. Al-Qudah, M. K. M., Osman, A., Ab Halim, M. S., \& Al-Shatanawi, H. A. (2014). The Effect of Human Resources Planning and Training and Development on Organizational Performance in the Government Sector in Jordan. International Journal of Academic Research in Business and Social Sciences, 4(4), 79-85.

7. Al-Qutop, M. A. Y., Moh'd Futa, S., \& Ma'ani, A. I. (2011). The relationship between learning facilitators and transforming into a learning organization: An empirical study of the insurance sector in Jordan. International Business Research, 4(3), 211-225.

8. Amoah-Mensah, A., \& Darkwa, P. (2016) Training \& development process and employees performance in the (Chop-Bar) industry, Journal of Research and Development (JRND) 3, (1) 34-57.

9. Argyris, C. (1991). Teaching smart people how to learn. Harvard Business Review 4 (2), 4-15.

10. Armstrong, M., \& Taylor, S. (2014). Armstrong's handbook of human resource management practice. $13^{\text {th }}$ Ed. London, Kogan Page Publishers.

11. Altarawneh, I. I. (2005). Training and development effectiveness: practices, roles and impacts on performance in Jordanian banking organizations (Doctoral dissertation, University of Huddersfield). available at: http://eprints.hud.ac.uk/id/eprint/4611/.

12. Bakir, S. M. A. (2017). The influence of strategic leadership on building employees' entrepreneurial orientation: A field study at the Jordanian Public Sector. International Business Research, 10(6), 6274.

13. Bataineh, K. (2014). Impacts of employee training on the performance of commercial banks in Jordan. European Journal of Business and Management, 6(27), 192-196. 
14. Bernardin, H. J. \& Russell, J. (2013). Human resource management: An experiential approach. $7^{\text {th }} \mathrm{Ed}$, Iowa McGraw-Hill

15. Bohalender W. G. \& Snell, S. (2013) principles of human resources management, $16^{\text {th }} \mathrm{Ed}$. Boston, South-Western, Cengage Learning.

16. Bonn, I. (2001), "Developing strategic thinking as a core competency”, Management Decision, 39( 1), 63-71.

17. Bonn, I. (2005). Improving strategic thinking: a multilevel approach. Leadership \& Organization Development Journal, 26(5), 336-354.

18. Buchanan, D. A., \& Huczynski, A. A. (2010). Organizational behavior $7^{\text {th }}$ Ed. , New York, Pearson education.

19. Calrk, W.. (2012). Introducing strategic thinking into a non-profit organization to develop alternative income streams. Journal of Practical Consulting, 4(1), 32-42.

20. Cortada, J. W. (2014). When knowledge transfer goes global: how people and organizations learned about information technology, 19451970. Enterprise \& Society, 15(1), 68-102.

21. Daft, R. (2012). Management, $10^{\text {th }} \mathrm{Ed}$, Mason Oh. South Western Cengage Learning.

22. David, Fred R. (2011). Strategic management: Concepts \& Cases. Upper Saddle River, New Jersey: PEARSON Prentice Hall.

23. DeCenzo D. A., and Robbins S. P (2015) Fundamentals of human resource management.., $11^{\text {th }}$ Ed., New Jersey , John Wiley \& Sons.

24. DeNisi A, Griffin R, (2010). Human Resource Management. $6^{\text {th }}$ Ed. Mason, OH: South-Western Cengage Learning.

25. Dessler G, 2014. Fundamentals of Human Resource Management, 3rd.Ed. Boston: Irwin Prentice Hall.

26. Díaz-Fernández, M., López-Cabrales, A., \& Valle-Cabrera, R. (2014). A contingent approach to the role of human capital and competencies on firm strategy. BRQ Business Research Quarterly, 17(3), 205-222.

27. Evans, J.D. (1996). Straightforward Statistics for the Behavioral Sciences. Brooks/Cole Publishing; Pacific Grove, Calif, available at:www.statstutor.ac.uk/resources/uploaded/pearsons

28. Falola, H. O., Osibanjo, A. O., \& Ojo, S. I. (2014). Effectiveness of training and development on employees' performance and organization competiveness in the Nigerian Banking Industry . Bulletin of the Transylvania University of Brasov. Economic Sciences. Series V, 7(1), 161-170.

29. French, S (2009) Re-framing strategic thinking: the research - aims and outcomes, Journal of Management Development, 28 (3),205224. 
30. Goldman, E. F., Scott, A. R., \& Follman, J. M. (2015). Organizational practices to develop strategic thinking. Journal of Strategy and Management, 8(2), 155-175. https://doi.org/10.1108/JSMA-01-2015$\underline{0003}$

31. Goldman, E., \& Scott, A. R. (2016). Competency models for assessing strategic thinking. Journal of Strategy and Management, 9(3), 258280.

32. Habib, A., Hossain, A. P. D. S., \& Essien, D. D. (2016). Assessing the effect of training on employees performance in Nigerian Hotle industry (a case study of Sheraton Hotel and Resorts Lagos). training and development, 5(4).pp 13-25

33. Hanif, F. (2013). Impact of training on employee's development and performance in hotel industry of lahore, pakistan. Journal of business studies quarterly, 4(4), 68-82.

34. Imran, M., \& Tanveer, A. (2015). Impact of traning and development on employees performance in banks of Pakistan, . European Journal of Training and Development Studies, 3(1), 22-44.

35. Ivancevich, J. M. (2010). Human Resource Management , $11^{\text {th }} \mathrm{Ed}$. , New York McGraw Hill.

36. Kateb, M., Swies, R., Obeidat, B., \& Maqableh, M. (2015). An investigation on the critical factors of information system implementation in Jordanian information technology companies. European Journal of Business and Management, 7(36), 11-28

37. Khan, D. M. (2014). HR as a Strategic Partner: A Critical Review. International Journal of Human Resource Studies, 4(1), 1-8.

38. Kotler, P., \& Keller, K. L. (2012). Marketing management 14e. Boston, Pearson Prentice Hall.

39. Krajewski, L. J., Ritzman, L. P., \& Malhotra, M. K. (2013). Operations management; processes and supply chains $\left(10^{\text {th }}\right.$ Ed $)$. Harlow: Pearson Education.

40. Kum, F. D., Cowden, R., \& Karodia, A. M. (2014). The impact of training and development on employee performance: A case study of ESCON Consulting. Singaporean Journal of Business Economics and Management Studies, 3(3), 72-105.

41. Kurec, A. (2014). Strategic planning without strategic thinking will fail. Clinical Leadership \& Management Review, 28(1), 16-21.

42. Liedtka, J. M. (1998). Strategic thinking: can it be taught?. Long range planning, 31(1), 120-129.

43. Lowder, B. Tim, (2009). Strategic thinking and strategic planning: two pieces of the same puzzle. Available at: http://dx.doi.org/10.2139/ssrn.1418793. 
44. Moh'd Futa, S. (2013). The relationship between social responsibility and organizational citizenship behavior in 5 stars hotels operating in Petra city. European Scientific Journal, ESJ, 9(14). 118-133.

45. Mello, J.A. (2015) Strategic human resource management.. $4^{\text {th }}$ Ed. . South-Western, Cengage Learning.

46. Mintzberg, H. (1994), "The fall and rise of strategic planning", Harvard Business Review, 72 (1), 107-114.

47. MTD Training (2010) thinking strategically, available at BookBoon.com

48. Naser, K. (2015). The impact of the Gulf War immigration on Jordan's economy and its information technology (IT) Sector. i-Manager's Journal on Management, 10(3), 6-19.

49. Noe, R. A. (2013). Employee training and development $6^{\text {th }}$ Ed. New York, McGraw-Hill Irwin.

50. Nolan, C. (2002). Human resource development in the Irish hotel industry: the case of the small firm. Journal of European Industrial Training, 26(2/3/4), 88-99.

51. Nuntamanop, P., Kauranen, I., \& Igel, B. (2013). A new model of strategic thinking competency. Journal of Strategy and Management, 6(3), 242-264.

52. Obi-Anike, H. O., \& Ekwe, M. C. (2014). Impact of training and development on organizational effectiveness: evidence from selected Public Sector organizations in Nigeria. European Journal of Business and Management, 6(29), 66-75.

53. Oni-Ojo, E. E., Salau, O. P., Oludayo, O. O., \& Abasilim, U. D. (2014). Strategic Role of Human Resource Training and Development on Organizational Effectiveness in Nigerian

54. Banking Industries. Global Journal of Human Resource Management, 2(4), 24-39.

55. O'Shannassy, T. (2003). Modern strategic management: Balancing strategic thinking and strategic planning for internal and external stakeholders. Singapore Management Review, 25(1), 53-75.

56. Pahl-Wostl, C. 2009. A conceptual framework for analyzing adaptive capacity and multi-level learning processes in resource governance regimes. Global Environmental Change 19(3):354-365

57. Pattinson, S. (2016). Strategic thinking: intelligent opportunism and emergent strategy, the case of strategic engineering services. The International Journal of Entrepreneurship and Innovation, 17(1), 6570.

58. Richmond, B. (1993). Systems thinking: critical thinking skills for the 1990s and beyond. System dynamics review, 9(2), 113-133.

59. Robbins , S. P., \& Judge, T. A. (2013), Organizational behavior, 
$15^{\text {th }}$ Ed. Boston, Pearson Prentice-Hall.

60. Robbins, S. P., \& Coulter, M., (2012) Management, $11^{\text {th }}$ Ed, Boston, Pearson Prentice Hall

61. Salavati, S., Amerzadeh, M., Mohammadi Bolbanabad, A., Piroozi, B., \& Amirihoseini, S. (2017). Evaluation of strategic thinking and its affecting factors among managers and personnel in a medical sciences university in Iran. International Journal of Human Rights in Healthcare, 10(4), 248-255.

62. Saleem, Q., Shahid, M., \& Naseem, A. (2011). Degree of influence of training and development on employee's behavior. International Journal of Computing and Business Research, 2(3), 2229-6166.

63. Saunders, M., Lewis, P., \& Thornhill, A. (2013). Research methods for business students, $6^{\text {th }}$ Ed.. Harlow, Pearson education.

64. Sekaran, U. (2003)Research methods for business: A skill building approach (4 th ed.). New York, NY. John Wiley \& Sons.

65. Senge P (1990) The fifth discipline: The art and practice of the learning organization. Century Business, London

66. Sharifi, E. (2012). Strategic thinking; a practical view. Ideal type of management, 1(1), 71-84.

67. Smith, A., Courvisanos, J., Tuck, J., \& McEachern, S. (2012). Building the Capacity to Innovate: The Role of Human Capital. Research Report. National Centre for Vocational Education Research. available at: https://www.ncver.edu.au/research..

68. Tahir, N., Yousafzai, I. K., Jan, S., \& Hashim, M. (2014). The impact of training and development on employees performance and productivity A case study of United Bank Limited Peshawar City, KPK, Pakistan. International Journal of Academic Research in Business and Social Sciences, 4(4), 86-98.

69. Torrington D., Hall, L., Taylor, S., \& Atkinson, C (2011), Human resource management, $9^{\text {th }}$ Ed., Harlow, Pearson Education Limited.

70. Ugbomhe, U. O., Osagie, G. N., \& Egwu, U. E. (2016). Impact of training and development on employee performance in selected banks in Edo North Senatorial District, Nigeria. Indian Journal of Commerce \& Management Studies, 7(3), 48-55.

71. Werner, J. M., \& DeSimone, R. L. (2012). Human resource development. $6^{\text {th }}$ Ed. Cengage Learning.

72. Wheelen, T. L. \& Hunger, D (2012) Strategic management and business policy: toward global sustainability, $13^{\text {th }} \mathrm{Ed}$. Boston, Pearson Education, Inc.,

73. Zikmund, W.G (2003) Business research methods, $7^{\text {th }}$ Ed, Mason" Thomson Learning . 